\title{
Traditional Medicine Followed at the Heart Institute of Abidjan
}

\author{
Fatoumata Traoré*, Kamagaté Djenamba Bamba, Yves N'da Kouakou Ngoran, Florent Koffi, \\ Marie Paule Mottoh, Soya Esaie, I. Coulibaly
}

Heart Institute of Abidjan, Abidjan, Côte d'Ivoire

Email: *Traofa@yahoo.fr

How to cite this paper: Traore, F., Bamba, K.D., Koffi, F., Ngoran, Y.N.K., Mottoh, M.P., Esaie, S. and Coulibaly, I. (2017) Traditional Medicine Followed at the Heart Institute of Abidjan. World Journal of Cardiovascular Diseases, 7, 292-298.

https://doi.org/10.4236/wjcd.2017.79027

Received: August 10, 2017

Accepted: September 19, 2017

Published: September 22, 2017

Copyright $\odot 2017$ by authors and Scientific Research Publishing Inc. This work is licensed under the Creative Commons Attribution International License (CC BY 4.0).

http://creativecommons.org/licenses/by/4.0/

(c) (i) Open Access

\begin{abstract}
Objective: To determine the prevalence of the use of traditional medicine in hypertensive patients and to identify the socio-demographic characteristics of these patients. Materials and Methods: This is a single cross-sectional study with descriptive purpose that was carried out over a 4 month-period, from 1 January 2017 to 30 April 2017, in the outpatient department of the Heart Institute of Abidjan. It involved patients who consulted during this period for high blood pressure. An informed questionnaire was submitted to patients. A pre-test was performed on 20 patients prior to the start of the survey. Results: The prevalence was $34 \%$, with a slight male predominance $(52.4 \%)$. The average age of our patients was 51.7 years \pm 20 years. Males $(52.4 \%)$ and females $(47.6 \%)$ were roughly in the same proportions in our study with a slight male predominance. Patients with a higher level of education used traditional medicine in $30.6 \%$ that is about one third of the cases. Nearly one third of the patients had a monthly income above 300,000 FCFA (28.5\%). Almost half of the patients (45\%) had social insurance coverage. Conclusion: The use of traditional medicine by hypertensive patients is a practice that exists and is growing rapidly. The profile of hypertensive patients using traditional medicine can be summarized as a young subject, a male with a higher education level, a high monthly income and social coverage. It is the place to insist on the therapeutic education of our hypertensive patients' only way for a good control of the blood pressure figures.
\end{abstract}

\section{Keywords}

Traditional Medicine, High Blood Pressure

\section{Introduction}

According to the WHO, traditional medicine refers to "health practices, me- 
thods, knowledge and beliefs that involve the use for medical purposes of plants, parts of animals and minerals, spiritual therapies, techniques and manual exercises, separately or in combination, to treat, diagnose and prevent disease or to protect health" [1].

In Africa, Asia and Latin America, different countries use traditional medicine to meet some of their primary health care needs. It is estimated that $80 \%$ of Africans use traditional medicine to treat themselves [1]. Harris Memel-Fote [2] in Cote d'Ivoire states that the quest for health as a source of life justifies and explains the use of all the means that can restore or do recover health. Who is this African who can claim to have not received since his childhood has a traditional treatment? [3].

In the industrialized countries, "complementary" or "parallel" or "alternative" medicine is the equivalent of traditional medicine [1].

However, in Africa, little work has been done on this traditional practice and we do not have local data. It is therefore appropriate to determine the prevalence of the use of traditional medicine in a population of hypertensive patients and to identify the socio-demographic characteristics of these patients in our context (Figure 1).

\section{Materials and Methods}

This is a single cross-sectional study with descriptive purpose that was carried out over a four-month period from 1 January 2017 to 30 April 2017. This study involved patients who consulted during this period for high blood pressure.

An informed questionnaire was submitted to patients. It included the socio-demographic, clinical, therapeutic characteristics, the reasons for the use of medicinal plants (Table 1).

A pre-test was performed on 30 patients before the start of the survey.

We carried out this work in the outpatient department of the Heart Institute of Abidjan. In our study, the majority of conventional medicines cost more than 10,000 FCFA/month (72.7\%).

\section{Inclusion Criteria}

Were included in our study, all known hypertensive patients, over the age of

- Use of traditional medicine

- Non-use of traditional medicine

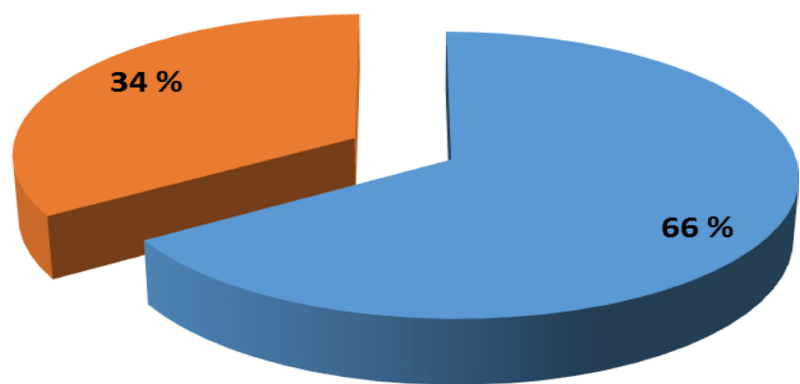

Figure 1. The prevalence of hypertensive patients using the medicine traditional was $34 \%$. 
Table 1. Socio-demographic characteristics of users and non-users of traditional medicine.

\begin{tabular}{|c|c|c|c|c|}
\hline & & $\begin{array}{l}\text { Traditional medicine } \\
\text { users }(\mathrm{n}=330)\end{array}$ & $\begin{array}{c}\text { Non users of } \\
\text { traditional medicine } \\
(\mathrm{n}=630)\end{array}$ & $\mathrm{P}$ \\
\hline \multicolumn{2}{|c|}{ Age (years) } & 51.7 & 57.6 & 0.395 \\
\hline \multicolumn{2}{|c|}{ Gender $(\mathrm{M} / \mathrm{F})$} & $52.4 / 47.6$ & $53.8 / 46.2$ & 0.777 \\
\hline \multirow{4}{*}{ Educaton level } & Uneducated & 33.6 & 31.4 & 0.651 \\
\hline & Primary & 15.8 & 12.9 & 0.547 \\
\hline & Secondary & 20 & 37.9 & 0.005 \\
\hline & Higher & 30.6 & 17.9 & 0.033 \\
\hline \multirow{3}{*}{ Monthly income } & $<100,000$ FCFA & 37 & 33.7 & 0.658 \\
\hline & 100,000 à 300,000 FCFA & 34.5 & 53.7 & 0.007 \\
\hline & $>300,000 \mathrm{FCFA}$ & 28.5 & 12.6 & 0.005 \\
\hline \multirow{2}{*}{ Social security cover } & Yes & 44.9 & 42.4 & 0.009 \\
\hline & No & 55.1 & 57.6 & 0.051 \\
\hline \multirow{3}{*}{$\begin{array}{c}\text { Cost of } \\
\text { Conventional } \\
\text { treatment }\end{array}$} & $<10,000$ FCFA & 27.3 & 18.5 & 0.005 \\
\hline & 10,000 à 20,000 FCFA & 35.2 & 42.9 & 0.06 \\
\hline & $>20,000$ FCFA & 37.5 & 38.7 & 0.008 \\
\hline
\end{tabular}

FCFA $=$ Francs of the Financial Community in Africa; 1 DOLLAR $=600$ FRANCS CFA.

18 years, followed and treated for more than three months and who have recognized the use of traditional medicine in addition to conventional medicine.

\section{Non-Inclusion Criteria}

Were not included hypertensive patients under the age of 18 years who were treated and followed at the Heart Institute of Abidjan for less than 3 months and those who used only conventional treatment?

The number of patients to interview was not initially determined.

At the end of the survey, 960 hypertensive patients were interviewed and 330 were found users of traditional medicine and $630 \mathrm{did}$ not use traditional medicine.

Data processing was performed using Epi Info software version 6.0.

The averages were compared using the test of STUDENT at the 5\% threshold.

\section{Results}

The prevalence makes it possible to assess or to express, over a 4 month-period, all the hypertensive patients who have recognized the use of traditional medicine in addition to conventional treatment out of the number of patients interviewed during the same period, that is $330 / 960=0.34(34 \%)$.

Males (52.4\%) and females (47.6\%) were distributed roughly in the same proportions in our study with a slight male predominance. The mean age of patients was 51.7 years with a significant proportion of patients in the age group (40 70). Patients with a higher level of education used traditional medicine in $30.6 \%$.

Nearly one-third of patients had a monthly income above 300,000 FCFA 
$(28.5 \%)$

In our study, the majority of conventional drugs cost more than 10,000 FCFA/month (72.7\%).

\section{Discussion}

\section{PREVALENCE}

The prevalence of the use of traditional medicine in our sample was $34 \%$. Elsewhere, EISENBERG [4] [5] in the USA and SHAFIQ in INDIA [6] found higher rates of $40 \%$ and $38.5 \%$. In AFRICA and specifically in NIGERIA, ALUWATOYIN [7] also found $39.1 \%$. This highlights the extent of this practice both in AFRICA and elsewhere in the world.

In the UNITED STATES, almost $40 \%$ of patients do not tell their doctors about the parallel use of these traditional products [4].

\section{SOCIODEMOGRAPHIC CHARACTERISTICS}

\section{1) Gender}

In the group of patients using traditional medicine, men account for (52.4\%) and women (47.6\%) with a slight male predominance. This distribution is similar to that of the group of patients not using traditional medicine with a statistically insignificant difference. This male dominance is a reflection of the overall distribution of the population in COTE D'IVOIRE [8]. EKOU in his study also found a male predominance [9]. Differences have been observed with other studies, notably that of DIALLO BA [10] in the cardiology consultation department in MALI and TWAGIRUMUKIZA [11] in the internal medicine department in RWANDA. This male predominance does not seem to be universally recognized. In reality, this sex ratio is related to age. Before age 50 men are more hypertensive than women and beyond 50 years, women are more often hypertensive than men [9].

\section{2) Age}

In our study, the average age of patients was 51.7 years for traditional medicine users and 57.6 years for non-users of traditional medicine. This difference is significantly insignificant. Our results are close to those of EKOU [9] in the outpatient department of the Heart Institute of Abidjan who found an average age of $54 \pm 13.8$ with a high proportion in the age group of $50-59$ [6]. MOUANODJI [12] in TCHAD notes that $65.5 \%$ of hypertensive patients are over 50 years of age. In fact, the prevalence of high blood pressure increases with the age of patients, which is also an independent cardiovascular risk factor [9].

3) Education level, socio-professional category, monthly income, social security cover, monthly cost of conventional treatment.

In our study, patients with a higher level of education used traditional medicine in $30.6 \%$ versus $17.9 \%$ in the group of patients with a higher level of education who do not use traditional medicine with a statistically significant difference.

Our results are close to those of OLUWATOYIN [7] in NIGERIA who found 
that the proportion of subjects with tertiary education was 23.6\%. EISENBERG in the United States [4] and MACLENNAN [5] in Australia observed a higher rate of $40 \%$.

Nearly one-third of patients using traditional medicine had a monthly income above 300,000 FCFA $(28.5 \%)$ vs. (12.6\%) in the group of those not using traditional medicine. Our observations are close to those of Eisenberg [4] in the United States and to those of MACLENNAN [5] in AUSTRALIA, who found that $30 \%$ of patients using traditional medicine had a high monthly income. On the other hand OLUWATOYIN [7] in NIGERIA found that $66.2 \%$ of patients had low monthly income. Indeed, patients considered to be easily able to meet their health needs use traditional medicine.

Almost half of the patients using traditional medicine had social coverage (45\%) versus $42.4 \%$ who did not use traditional medicine. It could be understood that the lack of social protection would favor traditional medicine, which is not the case.

In our study, education level, monthly income and social coverage have no influence on the use of traditional medicine which means that the difference observed is statistically insignificant. Patients' use of traditional medicine would be related to cultural influences, perceptions of the efficacy of traditional medicine, media-led efforts to promote traditional medicine, side effects of some Antihypertensive drugs especially on erectile function in men and finally the failure of modern medicine to treat the underlying problem could explain these facts. CLEMENT [13] in TRINITE agreed saying that cultural beliefs and perceptions of the efficacy of traditional medicine outweigh socio-economic factors.

HARRIS MEMEL-FOTE [2] in COTE D'IVOIRE found that $62.5 \%$ of respondents who were treated by traditional doctors had a higher level of education. Data confirm that the belief in the activity of traditional doctors is still alive. The majority of respondents keep on believing in the efficacy of traditional medicine.

\section{4) The cost of conventional treatment}

In our study, the majority of conventional medicines cost more than 10,000 FCFA/month (72.7\%) that is 16 euro/month for those who used traditional medicine against $(81.6 \%)$ for those not using traditional medicine with a statistically insignificant difference. Our results are close to those of NGUETTA [14] in COTE D'IVOIRE who found that the monthly cost of the management of high blood pressure was 23,900 FCFA, $48.6 \%$ of which was used for medicines that is 11,615 FCFA.

\section{The Limits of Our Study}

The limitations of our study are the difficult appraisal of the monthly income which represents a taboo for our fellow citizens and the socioeconomic level. In reality the socio economic level must take into account in addition to the monthly income, the number of people in charge, type of housing and the pres- 
ence of water and electricity.

\section{Conclusion}

The use of traditional medicine by hypertensive patients is a practice that exists and is growing rapidly. The profile of hypertensive patients using traditional medicine can be summarized as a young subject, a male with a higher education level, a high monthly income and social coverage. It is the place to insist on the therapeutic education of our hypertensive patients' only way for a good control of the blood pressure figures.

\section{References}

[1] Organisation Mondiale De La Santé. Aide-mémoire no. 134 révisé mai 2003.

[2] Harris, M.F., et al. (1998) Representations of Health and Illness in the Ivorian. Edition L'Harmattan, p. 162.

[3] Applied Development Science Research Unit. Traditional Medicine of Central Africa, 2007, No. 1 .

[4] Eisenberg, D.M., Davis, R.B., Ettner, S.L., Wilkey, S., Van Rompay, M. and Kessler, R.C. (1998) Trends in Alternative Medicine Use in the United State, 1990-1997: Result of a Follow National Survey. JAMA, 280, 1569-1575.

https://doi.org/10.1001/jama.280.18.1569

[5] Eisenberg, D.M., Kessler, R.C., Foster, C., Norlock, F.E., Calkins, D.R. and Delbanco, T.L. (1993) Unconventional Medicine in United States-Prevalence, Osts, and Patterns of Use. The New England Journal of Medicine, 328, 246-252. https://doi.org/10.1056/NEJM199301283280406

[6] Shafiq, N., Gupta, M. and Kumari, S. (2003) Pandhi Prevalence and Pattern of Use of Complementary and Alternative Medicine (CAM) in Hypertensive Patients of a Tertiary Care Center in India. International Journal of Clinical Pharmacology and Therapeutics, 41, 294-298. https://doi.org/10.5414/CPP41294

[7] Oluwatoyin, C. and Okubadejo, N.U. (2007) Frequency of Complementary and Alternative Medicine Utilization in Hypertensive Patients Attending an Urban Tertiary Care Center in Nigeria. BioMed Central, 10, 1186-1187.

[8] Bi, T.Z. (2008) Abidjan National Institute of Statistics. Retrieved on September 12, 2008. Available on http://fr.wikipedia.org/wiki/D\%C3\%A9mographie_de_la_C\%C3\%B

[9] Ekou, K.A.C. (2006) Contribution to the Study of Hypertension in the ICA. Medicine Thesis, Abidjan Cote d'Ivoire.

[10] Diallo, B.A. (1994) Epidemiological Profile of the HTA in Hospitals in Bamako. Medecine of Black Africa, 41, 103-105.

[11] Twagirumukiza, M. and Gasakure, E. (2003) Aspects of Hypertension in the Service of Internal Medicine at the Butare University Hospital: Prospective Study about 144 Cases. Medecine of Black Africa, 50, 169-175.

[12] Mouanodji, M.B. (1996) Aspects Epidemiological, Clinical and Evolutionary High Blood Pressure in a Hospital in N'Djamena about 1188 Case. Medicine in Africa Black, 43, 580-584.

[13] Clement, Y.N., Morton-Gittenss, J., Basdeo, L., Blades, A., Francis, M.J., Gomes, N., et al. (2007) Perceived Efficacy of Herbal Remedies by Users Accessing Primary 
Healthcare in Trinidad. BMC Complement.

[14] Nguetta, R., Adoh, M., Adoubi, A., Dionkounda, A., Brou, I., Traofa, F. and Koffi, J. (2006) Cout direct de la prise en charge ambulatoire de l'hypertension artérielle à Abidjan. Afrique biomédicale, 11, 1.

Submit or recommend next manuscript to SCIRP and we will provide best service for you:

Accepting pre-submission inquiries through Email, Facebook, LinkedIn, Twitter, etc. A wide selection of journals (inclusive of 9 subjects, more than 200 journals)

Providing 24-hour high-quality service

User-friendly online submission system

Fair and swift peer-review system

Efficient typesetting and proofreading procedure

Display of the result of downloads and visits, as well as the number of cited articles Maximum dissemination of your research work

Submit your manuscript at: http://papersubmission.scirp.org/

Or contact wjcd@scirp.org 